Journal of Economic, Business and Accounting (COSTING)

Volume 2 Nomor 1, Juli-Desember 2018

e-ISSN : 2597-5234

https://doi.org/10.31539/costing.v2i1.369

\title{
ANALISIS FAKTOR-FAKTOR YANG MEMPENGARUHI POLA KONSUMSI PANGAN RUMAH TANGGA
}

\section{ANALYSIS OF FACTORS AFFECTING HOUSEHOLD \\ FOOD CONSUMPTION PATTERN}

\author{
Siska Alfiati \\ STIE Prabumulih \\ siskaalfiati@gmail.com
}

\begin{abstract}
Food has become a primary human need that must be fulfilled before fulfilling other living needs such as clothing, housing and education. This study aims to analyze food consumption patterns and factors that influence the food consumption patterns of households in Prabumulih City. The method of analysis is done by tabulating data, then analyzed using the calculation of energy consumption adequacy based on the PPH reference. To analyze the influencing factors carried out using multiple linear regression analysis. Sampling is done by simple random sampling method as many as 100 housewives. The results of this study indicate that the food consumption patterns of households in Prabumulih City have not reached ideal numbers. Simultaneously the income variable, the number of family members, the age of the mother, the level of maternal education significantly influence the food consumption patterns of households in Prabumulih City, while partially the income and number of families have a significant effect on household food consumption patterns in Prabumulih City.
\end{abstract}

Keywords: Pattern of Food Consumption, Household.

\begin{abstract}
ABSTRAK
Pangan telah menjadi kebutuhan primer manusia yang harus dipenuhi sebelum memenuhi kebutuhan hidup lainnya seperti sandang, papan dan pendidikan. Penelitian ini bertujuan untuk menganalisis pola konsumsi pangan dan faktor-faktor yang mempengaruhi pola konsumsi pangan rumah tangga di Kota Prabumulih. Metode analisis dilakukan dengan tabulasi data, selanjutnya dianalisis dengan menggunakan perhitungan kecukupan konsumsi energi berdasarkan acuan PPH. Untuk menganalisis faktor-faktor yang mempengaruhi dilakukan menggunakan analisis regresi linier berganda. Pengambilan sampel dilakukan dengan metode simple random sampling sebanyak 100 ibu rumah tangga. Hasil penelitian ini menunjukkan pola konsumsi pangan rumah tangga di Kota Prabumulih belum mencapai angka ideal. Secara serempak variabel pendapatan, jumlah anggota keluarga, umur ibu, tingkat pendidikan ibu berpengaruh nyata terhadap pola konsumsi pangan rumah tangga di Kota Prabumulih, sedangkan secara parsial pendapatan dan jumlah keluarga berpengaruh nyata terhadap pola konsumsi pangan rumah tangga di Kota Prabumulih.
\end{abstract}

Kata Kunci : Pola Konsumsi Pangan, Rumah Tangga. 


\section{PENDAHULUAN}

Pangan merupakan kebutuhan dasar yang paling esensial bagi manusia untuk mempertahankan hidup. Manusia sebagai makhluk hidup, tanpa pangan tidak mungkin dapat melangsungkan hidup dan bermasyarakat. Tidak dapat dipungkiri lagi bahwa sejak dulu hingga nanti pun manusia memerlukan bahan pangan untuk bertahan hidup. Pangan telah menjadi kebutuhan primer manusia yang harus dipenuhi sebelum memenuhi kebutuhan hidup lainnya seperti sandang, papan dan pendidikan (Sari, Nina Tama; 2007).

Kualitas dan kuantitas konsumsi pangan oleh setiap individu akan mempengaruhi status ketahanan pangan individu tersebut. Ketersediaan pangan dalam rumah tangga merupakan salah satu indikator keberhasilan ketahanan pangan dalam rumah tangga itu sendiri. Menurut Kusumawati (2013), terwujudnya ketahanan pangan sampai pada tingkat rumah tangga berarti mampu memperoleh pangan yang cukup jumlah, mutu, dan beragam untuk memenuhi kebutuhan pangan dan gizi. Cukup disini berarti tidak hanya beras tetapi mencakup pangan non beras yang berasal dari tanaman, ternak, dan ikan untuk memenuhi kebutuhan atas karbohidrat, lemak, protein, vitamin, dan mineral yang bermanfaat bagi pertumbuhan kesehatan manusia.

Pola konsumsi pangan antar rumah tangga dapat berbeda-beda, hal ini dipengaruhi oleh berbagai faktor misalnya ketersediaan pangan, sosial budaya, pengetahuan gizi, ekonomi dan lingkungan. Salah satu faktor yang sangat berpengaruh adalah faktor pendapatan. Tinggi rendahnya pendapatan suatu rumah tangga dapat mempengaruhi rumah tangga dalam memilih dan menentukan jenis pangan yang bermutu gizi baik yang beragam dan berimbang. Karena itu, perubahan pada faktor-faktor tersebut akan menyebabkan pola konsumsi pangan suatu rumah tangga (Dewi, I.S., dkk ; 2016).

Kota Prabumulih merupakan kota dengan latar belakang penduduk yang cukup heterogen, dengan berbagai tingkatan pendapatan, pekerjaan, suku, dan agama. Untuk itu maka pada penelitian ini peneliti tertarik untuk melakukan penelitian tentang pola konsumsi pangan rumah tangga dan faktor-faktor yang mempengaruhinya.

\section{METODE PENELITIAN}

Penentuan daerah penelitian dilakukan secara sengaja (purposive) di Kota Prabumulih Sumatera Selatan. Kota Prabumulih memiliki luas wilayah sebesar 251,94 km2 dengan jumlah penduduk sebanyak 193.829 jiwa. Pemilihan daerah penelitian dikarenakan daerah tersebut merupakan salah satu kota yang sedang berkembang dengan latar belakang penduduk yang heterogen.

Metode pengambilan sampel dilakukan dengan metode Slovin dengan persamaan sebagai berikut : 


$$
\mathrm{n}=\frac{N}{1+N e^{2}}
$$

dimana : $\mathrm{N}=$ ukuran populasi

$$
\mathrm{n}=\text { ukuran sampel }
$$$$
\mathrm{e}=\text { batas toleransi kesalahan }
$$

Dengan jumlah populasi rumah tangga sebanyak $41.843 \mathrm{KK}$ dan batas eror toleransi sebesar $10 \%$, maka hasil perhitungan diperoleh jumlah sampel sebanyak 99,76 atau 100 orang. Metode yang digunakan dalam penarikan sampel pada penelitian ini adalah metode pengambilan sampel aksidental (Accidental Sampling), yaitu metode pengambilan sampel yang ditentukan berdasarkan orang yang ditemui secara kebetulan atau siapapun yang dipandang oleh peneliti cocok sebagai sumber data.

Untuk identifikasi masalah yang Pertama, dianalisis secara deskriptif yaitu dengan mengamati dan menganalisis pola konsumsi pangan rumah tangga. Pengamatan pola konsumsi pangan ini dilaksanakan melalui wawancara dengan menggunakan kuesioner. Kemudian hasil wawancara dibentuk dalam tabulasi data, selanjutnya dianalisis dengan menggunakan perhitungan kecukupan konsumsi energi berdasarkan acuan PPH dengan formula sebagai berikut :

1. Konsumsi Aktual

KonsumsiAktual Konsumsi Pangan Rumah Tangga Jumlah Anggota Rumah Tangga

2. Energi Aktual

Energi Aktual $=$ $\frac{\text { Konsumsi Pangan Aktual }}{\text { Konsumsi Harapan }} x$ faktor konversi kkal

3. $\%$ Aktual

$\%$ Aktual =

$\frac{\text { Konsumsi Pangan Aktual }}{\text { Total Konsumsi Pangan Aktual }} \times 100 \%$

4. $\% \mathrm{AKE}$

$\% \mathrm{AKE}=\frac{\text { Energi Aktual }}{2000} \times 100 \%$

5. Bobot merupakan penentuan bobot (Triguna Pangan)

6. Skor Aktual $=\%$ Aktual $\mathrm{x}$ Bobot

7. Skor $\mathrm{AKE}=\% \mathrm{AKE} \times$ Bobot

8. Skor $\mathrm{PPH}=$ Jika skor $\mathrm{AKE}>$ dari skor maks, maka skor maks yang digunakan di dalam tabel skor PPH dan sebaliknya

Penentuan Bobot (Triguna Pangan) :

1. Sumber energi (karbohidrat) = $33,33 \%$

Padi-padian (50\%), umbi-umbian (6\%), minyak dan lemak (10\%), buah/biji berminyak (3\%), gula $(5 \%)$. Bobot $=33,33 \% / 74 \%=0,5$.

2. Sumber pembangun (protein) = $33,33 \%$

Pangan hewani (12\%), kacangkacangan $(5 \%)$. Bobot = $33,33 \% / 17 \%=2$.

3. Sumber pengatur (vitamin dan mineral $)=33,33 \%$

Sayur dan buah $(6 \%)$. Bobot $=$ $33,33 \% / 6 \%=5$.

4. Lain-lain $(0,1 \%)$

Bumbu-bumbuan dan minuman $(3 \%)$. Bobot $=0,1 \% / 3 \%=0,03$ 
Tabel 1. Faktor Konversi (Kkal) dan Skor Pola Pangan Harapan (PPH)

\begin{tabular}{|c|c|c|c|c|}
\hline \multirow[t]{2}{*}{ No. } & \multirow[t]{2}{*}{ Kelompok Pangan } & \multicolumn{2}{|c|}{$\begin{array}{c}\text { Faktor } \\
\text { Konversi }\end{array}$} & \multirow{2}{*}{$\begin{array}{l}\text { Skor } \\
\text { PPH } \\
\text { Ideal } \\
\end{array}$} \\
\hline & & $\mathbf{G r}$ & kkal & \\
\hline 1. & Padi-padian & 275 & 1000 & 25,0 \\
\hline 2. & Umbi-umbian & 90 & 120 & 2,5 \\
\hline 3. & Pangan hewani & 140 & 240 & 24,0 \\
\hline 4. & Minyak dan Lemak & 25 & 200 & 5,0 \\
\hline 5. & Buah/biji berminyak & 10 & 60 & 1,0 \\
\hline 6. & Kacang-kacangan & 35 & 100 & 10,0 \\
\hline 7. & Gula & 30 & 100 & 2,5 \\
\hline 8. & Sayur dan Buah & 230 & 120 & 30,0 \\
\hline 9. & Lain-lain & 15 & 60 & 0,0 \\
\hline & Total & 850 & 2000 & 100 \\
\hline
\end{tabular}

Sumber : Badan Ketahanan Pangan, 2015

Untuk identifikasi masalah yang kedua, dianalisis menggunakan analisis regresi linier berganda melalui Program SPSS (Statistical Product and Services Solution). Untuk mengetahui pengaruh variabel bebas (pendapatan rumah tangga, jumlah anggota keluarga, umur dan tingkat pendidikan ibu rumah tangga terhadap variabel terikat yaitu total konsumsi pangan aktual rumah tangga.

Model regresi linier berganda yang digunakan :

$\hat{Y}=a+b_{1} X_{1}+b_{2} X_{2}+b_{3} X_{3}+b_{4} X_{4}+\mu$

Dimana :

Ý = Total konsumsi pangan aktual rumah tangga (gr)

a $\quad=$ Intercept atau konstanta

$\mathrm{b}_{1}, \mathrm{~b}_{2}, \mathrm{~b}_{3}, \mathrm{~b}_{4}=$ Parameter koefisien regresi

$\mathrm{X}_{1}=$ Pendapatan rumah tangga (Rp/hari)

$\mathrm{X}_{2} \quad=$ Jumlah anggota

keluarga (jiwa)

$\mathrm{X}_{3}=$ Umur ibu rumah tangga (tahun)
$\mathrm{X}_{4} \quad=$ Tingkat pendidikan ibu rumah tangga (tahun)

$\mu \quad=$ error term (koefisien error)

HASIL DAN PEMBAHASAN

Pola Konsumsi Pangan Rumah

Tangga di Kota Prabumulih

Hasil penelitian menunjukkan bahwa pola konsumsi pangan atau tingkat keberagaman pangan rumah tangga di Kota Prabumulih adalah sebagai berikut :

Tabel 2. Data Keberagaman Pangan Rumah Tangga di Kota Prabumulih

\begin{tabular}{|c|c|c|c|c|c|c|c|}
\hline $\begin{array}{l}\text { Kelompok } \\
\text { Pangan }\end{array}$ & $\begin{array}{l}\text { Konsumsi } \\
\text { Aktual } \\
\text { (gr/kap/hr) }\end{array}$ & $\begin{array}{l}\text { Energi } \\
\text { Aktual } \\
\text { (kkal/ } \\
\text { kap/hr) }\end{array}$ & \begin{tabular}{l|}
$\%$ \\
$\mathrm{AKE}$
\end{tabular} & Bobot & $\begin{array}{l}\text { Skor } \\
\text { AKE }\end{array}$ & $\begin{array}{l}\text { Skor } \\
\text { Maks } \\
\text { PPH } \\
\text { Ideal }\end{array}$ & PPH \\
\hline Padi-padian & 253,67 & 922,45 & 46,12 & 0,5 & 23,06 & 25 & 23,06 \\
\hline Umbi- & 25,94 & 34,58 & 1,73 & 0,5 & 0,86 & 2,5 & 0,86 \\
\hline umbian & 131,08 & 224,70 & 11,24 & 2 & 22,47 & 24 & 22,47 \\
\hline Pangan & & & & & & & \\
\hline Hewani & 32,02 & 256,12 & 12,81 & 0,5 & 6,40 & 5 & 5 \\
\hline Minyak dan & & & & & & & \\
\hline Lemak & 7,70 & 46,21 & 2,31 & 0,5 & 1,15 & 1 & 1 \\
\hline Buah/biji & & & & & & & \\
\hline $\begin{array}{l}\text { Berminyak } \\
\text { Kacang- }\end{array}$ & 41,68 & 119,08 & 5,95 & 2 & 11,91 & 10 & 10 \\
\hline kacangan & 29,71 & 99,02 & 4,95 & 0,5 & 2,47 & 2,5 & 2,47 \\
\hline Gula & 117,88 & 61,50 & 3,07 & 5 & 15,37 & 30 & 15,37 \\
\hline Sayur dan & & & & & & & \\
\hline $\begin{array}{l}\text { Buah } \\
\text { Lain-lain }\end{array}$ & 28,94 & 115,77 & 5,79 & 0,03 & 0,17 & 0 & 0 \\
\hline Total & 668,61 & 1879,44 & 93,97 & 11,53 & 83,89 & 100 & 80,25 \\
\hline
\end{tabular}

Sumber: Data Diolah (2018)

Tabel 2 menunjukkan bahwa total konsumsi rumah tangga di Kota Prabumulih 668,61 gr/kap/hr. Hal ini berrati berat konsumsi pangan rumah tangga di Kota Prabumulih belum mencapai angka kecukupan yang dianjurkan yaitu sebesar $850 \mathrm{gr} / \mathrm{kap} / \mathrm{hr}$. Berat konsumsi pangan rumah tangga 
dari jumlah terbesar hingga terkecil yaitu padi-padian, pangan hewani, sayur dan buah, kacang-kacangan, minyak dan lemak, gula, lain-lain, umbiumbian, dan buah/biji berminyak.

Tabel 2 menunjukkan bahwa total konsumsi energi rumah tangga di Kota Prabumulih adalah sebesar 1879,44 $\mathrm{kkal} / \mathrm{kap} / \mathrm{hr}$ atau $93,97 \%$. Hal ini berarti konsumsi energi di Kota Prabumulih belum mencukupi angka kecukupan yang dianjurkan yaitu sebesar 2000 kkal/kap/hr. Kelompok pangan dengan energi yang terbesar hingga terkecil adalah padi-padian, minyak dan lemak, pangan hewani, kacang-kacangan, lainlain, gula, sayur dan buah, buah/biji berminyak, dan umbi-umbian.

Selanjutnya pada Tabel 2 ditunjukkan bahwa skor Pola Pangan Harapan (PPH) di kota Prabumulih adalah sebesar 80,25. Hal ini menunjukkan bahwa Kota Prabumulih belum mencapai target skor Pola Pangan harapan sebesar 95 yang telah ditetapkan oleh Badan Ketahanan Pangan pada tahun 2015.

Tabel 3. Perbandingan Konsumsi Ideal dan Konsumsi Rumah Tangga Kota Prabumulih

\begin{tabular}{|c|c|c|c|c|c|c|}
\hline \multirow{2}{*}{$\begin{array}{c}\text { Kelompok } \\
\text { Pangan }\end{array}$} & \multirow{2}{*}{$\begin{array}{c}\text { Konsumsi } \\
\text { Ideal }\end{array}$} & \multirow{2}{*}{$\begin{array}{c}\text { Aktual } \\
\text { Hasil }\end{array}$} & \multirow{2}{*}{$\begin{array}{c}\text { Konsumsi } \\
\text { Ideal }\end{array}$} & \multirow{2}{*}{$\begin{array}{l}\text { Energi } \\
\text { Hasil }\end{array}$} & \multicolumn{2}{|c|}{ \%AKE } \\
\hline & & & & & Ideal & $\overline{\mathrm{H}}$ \\
\hline Padi-padian & 275 & 253,67 & 1000 & 922,45 & 50 & 41 \\
\hline Umbi-umbian & 90 & 25,94 & 120 & 34,58 & 6 & \\
\hline Pangan & 140 & 131,08 & 240 & 224,70 & 12 & 1: \\
\hline Hewani & 25 & 32,02 & 200 & 256,12 & 10 & $1:$ \\
\hline Minyak dan & & & & & & \\
\hline Lemak & 10 & 7,70 & 60 & 46,21 & 3 & : \\
\hline Buah/biji & & & & & & \\
\hline Berminyak & 35 & 41,68 & 100 & 119,08 & 5 & : \\
\hline Kacang- & & & & & & \\
\hline kacangan & 30 & 29,71 & 100 & 99,02 & 5 & . \\
\hline Gula & 230 & 117,88 & 120 & 61,50 & 6 & : \\
\hline Sayur & 15 & 28,94 & 60 & 115,77 & 3 & : \\
\hline Buah & & & & & & \\
\hline Lain-lain & & & & & & \\
\hline & 850 & 668,61 & 2000 & 1879,44 & 100 & 9 \\
\hline
\end{tabular}

Sumber: Data Primer Diolah
Tabel 3 menunjukkan tingkat konsumsi pangan di Kota Prabumulih. Dapat dilihat bahwa berat konsumsi pangan di Kota Prabumulih belum mencapai angka ideal, begitu juga dengan konsumsi energi di Kota Prabumulih belum mencapai angka kecukupan yang dianjurkan. Dari kesembilah kelompok pangan, terdapat tiga kelompok pangan yang berada diatas angka ideal, yaitu minyak dan lemak, kacang-kacangan, dan lain-lain (minuman dan bumbu). Sedangkan kelompok pangan yang lain yaitu padipadian, umbi-umbian, pangan hewani, buah/biji berminyak, gula, sayur dan buah masih berada dibawah angka kecukupan yang dianjurkan.

Faktor-faktor yang Mempengaruhi Pola Konsumsi Pangan Rumah Tangga di Kota Prabumulih

Dalam penelitian ini terdapat 4 (empat) faktor yang mempengaruhi pola konsumsi pangan rumah tannga di Kota Prabumulih yaitu pendapatan, jumlah anggota keluarga, umur ibu, dan tingkat pendidikan ibu.

Setelah diuji dengan menggunakan SPSS diketahui bahwa pengaruh variabel bebas (pendapatan, jumlah anggota keluarga, umur ibu, dan tingkat pendidikan ibu) terhadap variabel terikat ( pola konsumsi pangan rumah tangga) seperti terlihat pada tabel di bawah ini : 
Tabel 4. Hasil Analisis Regresi Faktor-faktor yang Mempengaruhi

Pola Konsumsi Pangan Rumah Tangga di Kota Prabumulih

\begin{tabular}{clcc}
\hline No. & \multicolumn{1}{c}{ Variabel } & $\begin{array}{c}\text { Koef. } \\
\text { regresi }\end{array}$ & Sig. \\
\hline 1. & Konstanta & 721,325 & 0,000 \\
2. & Pendapatan & 0,001 & 0,001 \\
3. & Jumlah Anggota & $-41,590$ & 0,000 \\
4. & Keluarga & $-0,798$ & 0,524 \\
5. & Umur Ibu & 5,445 & 0,146 \\
& Tingkat Pendidikan & & \\
\hline & Ibu & & \\
\hline
\end{tabular}

Sumber: Data Primer Diolah

Dari Tabel 4 diperoleh persamaan:

$\mathrm{Y}=721,325+0,001 \mathrm{X}_{1}-41,590 \mathrm{X}_{2}-$ $0,798 \mathrm{X}_{3}+5,445 \mathrm{X}_{4}$

Dari model regresi didapat signifikansi $\mathrm{F}$ pada Tabel Anova adalah sebesar $0,000 \quad(<0,05)$. Hal ini menunjukkan bahwa $\mathrm{H} 0$ ditolak dan $\mathrm{H} 1$ diterima, yang berarti variabel bebas (pendapatan rumah tangga, jumlah anggota keluarga, umur ibu rumah tangga, dan tingkat pendidikan ibu) berpengaruh nyata terhadap variabel bebas (pola konsumsi pangan rumah tangga).

Secara parsial, variabel bebas ada yang berpengaruh nyata dan tidak berpengaruh nyata terhadap variabel terikat. Hasil estimasi menunjukkan bahwa variabel pendapatan dan jumlah anggota keluarga berpengaruh nyata terhadap pola konsumsi pangan rumah tangga. Hasil penelitian sejalan dengan penelitian Adiana \& Karmidi (2015) yang juga menyatakan bahwa pendapatan berpengaruh terhadap pola konsumsi pangan, namun bertolak belakang dengan hasil variabel umur ibu dan tingkat pendidikan ibu berpengaruh tidak nyata terhadap pola konsumsi pangan rumah tangga.
Menurut Murjana (2007), hukum Engel menyatakan bahwa rumah tangga yang mempunyai upah atau pendapatan rendah akan mengeluarkan sebagian besar pendapatannya untuk membeli kebutuhan pokok. Sebaliknya, rumah tangga yang berpendapatan tinggi akan membelanjakan sebagian kecil saja dari total pengeluaran untuk kebutuhan pokok.

Jumlah tanggungan keluarga merupakan salah satu faktor yang mempengaruhi pola konsumsi rumah tangga. Banyaknya anggota keluarga, maka pola konsumsinya semakin bervariasi karena masing-masing anggota rumah tangga belum tentu mempunyai selera yang sama. Jumlah anggota keluarga berkaitan dengan pendapatan rumah tangga yang akhirnya akan mempengaruhi pola konsumsi rumah tangga tersebut.

Menurut Rahardja dkk (2005) semakin tinggi pendidikan seseorang pengeluaran konsumsinya juga akan semakin tinggi, sehingga mempengaruhi pola konsumsi dan hubungannya positif. Pada saat seseorang atau keluarga memiliki pendidikan yang tinggi, 42 kebutuhan hidupnya semakin banyak. Kondisi ini disebabkan karena yang harus mereka penuhi bukan hanya sekedar kebutuhan untuk makan dan minum, tetapi juga kebutuhan informasi, pergaulan di masyarakat baik, dan kebutuhan akan pengakuan orang lain terhadap keberadaannya. 


\section{PENUTUP}

\section{Kesimpulan}

1. Pola konsumsi pangan rumah tangga di Kota Prabumulih belum mencapai angka ideal yaitu sebesar 80,25. Pola konsumsi pangan di Kota Prabumulih didominasi oleh kelompok padi-padian, kemudian menyusul pangan hewani, sayur dan buah, kacang-kacangan, minyak dan lemak, gula, lain-lain, umbi-umbian, dan buah/biji berminyak.

2. Secara serempak keempat faktor (pendapatan rumah tangga, jumlah anggota keluarga, umur ibu rumah tangga, dan tingkat pendidikan ibu) berpengaruh nyata terhadap pola konsumsi pangan rumah tangga. Secara parsial faktor pendapatan dan jumlah anggota keluarga berpengaruh nyata terhadap pola konsumsi pangan rumah tangga. Sedangkan faktor umur ibu dan tingkat pendidikan ibu berpengaruh tidak nyata terhadap pola konsumsi pangan rumah tangga.

\section{Saran}

1. Kepada masyarakat Kota Prabumulih agar lebih memperhatikan pola konsumsi pangannya agar lebih beragam dan berimbang agar dapat tercapai pola konsumsi pangan sesuai dengan standar ideal yang diharapkan.

2. Kepada Pemerintah setempat agar hendaknya memberikan sosialisasi mengenai pentingnya pemenuhan gizi pangan yang beragam dan berimbang. Hal ini diharapkan dapat meningkatkan kesejahteraan masyarakat dari segi tingkat konsumsi pangan aktual dan pencapaian skor Pola Pangan Harapan (PPH).

3. Kepada peneliti selanjutnya diharapkan untuk dapat meneliti gambaran konsumsi pangan aktual rumah tangga di daerah lain, membandingkan pola konsumsi pangan antara desa dan kota, meneliti gambaran pola konsumsi pangan antar beberapa etnis dan juga menganalisis faktor-faktor selain faktor yang di atas untuk melihat pengaruhnya terhadap konsumsi pangan aktual rumah tangga. 
DAFTAR PUSTAKA

Adiana, P,P,E. \& Karmini, N,L. (2015).

Pengaruh Pendapatan, Jumlah

Anggota Keluarga,Dan

Pendidikan Terhadap Pola

Konsumsi Rumah Tangga

Miskin di Kecamatan Gianyar.

Dewi, I.S. (2016). Analisis Faktorfaktor yang Mempengaruhi Pola

Konsumsi Pangan Rumah

Tangga Nelayan (Studi Kasus:

Desa Bagan Dalam Kecamatan

Tanjung Tiram Kabupaten Batu Bara). E-journal USU.

Kusumawati, T. D. (2013). Analisis

Ketersediaan Pangan Pokok dan

Pola Konsumsi Pangan Rumah

Tangga Petani di Kecamatan

Nogosari Kabupaten Boyolali.

Universitas Sebelas Maret.

Surakarta.

Murjana Yasa, I G. W. (2008).

Penanggulangan Kemiskinan

Berbasis Partisipasi Masyarakat

di Provinsi Bali. Jurnal Ekonomi dan Sosial Input

Raharja, Pratama dan Mandala Manurung. (2005). Teori

Ekonomi Makro. Jakarta: Fakultas Ekonomi Universitas Indonesia.

Sari, Nina Tama. (2007). Analisis Dampak Kenaikan Harga Beras Terhadap Pola Konsumsi Beras Rumah Tangga di Cipinang, Jakarta Timur. Skripsi. Program Studi Manajemen Agribisnis Fakultas Pertanian Institut Pertanian Bogor. 